\title{
Temperature effects on zoeal morphometric traits and intraspecific variability in the hairy crab Cancer setosus across latitude
}

\author{
Monika Weiss $\cdot$ Sven Thatje $\cdot$ Olaf Heilmayer
}

Received: 6 July 2009 / Accepted: 23 September 2009 / Published online: 8 October 2009

(C) Springer-Verlag and AWI 2009

\begin{abstract}
Phenotypic plasticity is an important but often ignored ability that enables organisms, within species-specific physiological limits, to respond to gradual or sudden extrinsic changes in their environment. In the marine realm, the early ontogeny of decapod crustaceans is among the best known examples to demonstrate a temperature-dependent phenotypic response. Here, we present morphometric results of larvae of the hairy crab Cancer setosus, the embryonic development of which took place at different temperatures at two different sites (Antofagasta, $23^{\circ} 45^{\prime} \mathrm{S}$; Puerto Montt, $41^{\circ} 44^{\prime}$ S) along the Chilean Coast. Zoea I larvae from Puerto Montt were significantly larger than those from Antofagasta, when considering embryonic development at the same temperature. Larvae from Puerto Montt reared at 12 and $16^{\circ} \mathrm{C}$ did not differ morphometrically, but sizes of larvae from Antofagasta kept at 16 and $20^{\circ} \mathrm{C}$ did, being larger at the colder temperature. Zoea II larvae reared in Antofagasta at three temperatures (16, 20, and $24^{\circ} \mathrm{C}$ ) showed the same pattern, with larger larvae at colder temperatures. Furthermore, larvae reared at $24^{\circ} \mathrm{C}$, showed deformations, suggesting that $24^{\circ} \mathrm{C}$, which
\end{abstract}

Communicated by H.-D. Franke.

\section{Weiss ( $\square)$}

Alfred Wegener Institute for Polar and Marine Research, Am Handelshafen 12, 27570 Bremerhaven, Germany

e-mail: monika.weiss@awi.de

\section{S. Thatje}

National Oceanography Centre, Southampton,

School of Ocean and Earth Science,

University of Southampton, European Way,

Southampton SO14 3ZH, UK

O. Heilmayer

German Aerospace Centre, 53227 Bonn, Germany coincides with temperatures found during strong EL Niño events, is indicative of the upper larval thermal tolerance limit. C. setosus is exposed to a wide temperature range across its distribution range of about $40^{\circ}$ of latitude. Phenotypic plasticity in larval offspring does furthermore enable this species to locally respond to the inter-decadal warming induced by El Niño. Morphological plasticity in this species does support previously reported energetic trade-offs with temperature throughout early ontogeny of this species, indicating that plasticity may be a key to a species' success to occupy a wide distribution range and/or to thrive under highly variable habitat conditions.

Keywords Brachyura - Early ontogeny · Morphological variability $\cdot$ El Niño $\cdot$ Humboldt Current . Chile

\section{Introduction}

Phenotypic plasticity in larval offspring of invertebrates has often been discussed as an important mechanism to respond to sudden changes in their habitat, namely temperature and food conditions (e.g. Criales and Anger 1986; Shirley et al. 1987). However, quantitative experimental studies on this subject are scarce and most insight is probably available from experimental laboratory studies of decapod crustaceans. There is evidence that phenotypic conditions of larvae may be indicative of their energetic status or conditions experienced during oogenesis like contrasting habitats (Silva et al. 2009) and including across geographic temperature gradients (Wehrtmann and Albornoz 1998; Wehrtmann and Kattner 1998; Thatje and Bacardit 2000; Giménez 2002). Most of this knowledge is limited to studies of caridean shrimp larvae (i.e. Criales and Anger 1986; Wehrtmann 1991), which may 
express high variability in, for example, larval developmental pathways, number of instars, and size and energy contents in response to food and temperature condition. In comparison, and despite known energetic trade-offs in crab eggs, phenotypic plasticity in crab larvae is generally assumed to be more conservative; a view that might be largely driven by the lack of sufficient information available to date (Anger 2001) and that has already been disproved, for example, for Neohelice (formerly Chasmagnathus) granulata (Pestana and Ostrensky 1995; Cuesta et al. 2002).

The hairy crab Cancer setosus (Molina 1782; synonymous $C$. polyodon Poeppig 1836) ranges in its distribution from Guayaquil in Ecuador $\left(2^{\circ} 13^{\prime} \mathrm{S}, 79^{\circ} 53^{\prime} \mathrm{W}\right)$ to the Peninsula of Taitao in Southern Chile $\left(46^{\circ} 00^{\prime} \mathrm{S}, 75^{\circ} 00^{\prime} \mathrm{W}\right)$ (Garth and Stephenson 1966) and is of commercial value to local artisanal fisheries (Wolff and Soto 1992; SERNAPESCA 2006; Thatje et al. 2008). The early ontogeny, which in C. setosus consists of five planktotrophic zoeal and one megalopa stage before reaching the first crab stage (Quintana and Saelzer 1986), is considered the most delicate part within the life cycle of brachyuran and in particular cancrid crabs (Anger 2001; Weiss et al. 2009a, b). A unique physiological plasticity to respond to latitudinal and seasonal changes in temperature has been observed in reproductive traits of $C$. setosus. Among the most conspicuous characteristics is a synchronisation of a single egg batch release with seasonality at the species southernmost distribution boundary in central southern Chile (Puerto Montt, $41^{\circ} 44^{\prime}$ S), contrasted by multiple annual ovipositions in northern Chile (Antofagasta, $23^{\circ} 45^{\prime}$ S) (Fischer and Thatje 2008). In addition, a correlation of changes in egg energy contents and temperature was observed along latitude as well as in subsequent ovipositions in the same female (Fischer and Thatje 2008; Fischer et al. 2009a). These findings are consistent with the concept of a latitudinal gradient in energy provisioning into offspring of a broad variety of marine invertebrates (for review see Thatje et al. 2005). The underlying pattern of larger eggs with better energy provisioning at colder temperatures (higher latitudes) is discussed to be an adaptive response to limited food supply and longer pelagic life stage phases (Thatje et al. 2005). The latitudinal cline in energy provisioning of eggs therewith corresponds with the energy demand of the embryo. Egg development is generally faster at higher temperatures, but causes an altered metabolic efficiency often resulting in a size reduction of later life stages. This has been shown for the Dungeness crab, Cancer magister (Shirley et al. 1987), the spider crab, Hyas araneus (Kunisch and Anger 1984) as well as for caridean shrimps like Nauticaris magellanica (Wehrtmann and Kattner 1998), Betaeus emarginatus (Wehrtmann and López 2003), and Pandalus borealis (Brillon et al. 2005) in laboratory cultures, and for Nauticaris magellanica from the field (Thatje and Bacardit 2000). In C. setosus eggs from a southern Chilean population were larger containing higher lipid content, resulting in bigger larvae than eggs from northern Chile (Fischer et al. 2009b). Egg development in the southern population is primarily based on the metabolism of energy rich lipids, which finally enhances the energetic fitness of the hatching larvae, and which has been discussed as an adaptive response to colder temperatures and prolonged egg and larval developmental time (Fischer et al. 2009b).

The size and elemental composition of eggs and hatchlings itself has been subject to some studies, but fewer studies have addressed the question of phenotypic effects on larvae (Shirley et al. 1987; Thatje and Bacardit 2000; Wehrtmann and Albornoz 2003). Following the assumption that larval size will follow the known latitudinal cline in egg size, we hypothesise that larvae from Puerto Montt have larger sizes and tested whether the temperature experienced during embryonic development triggers phenotypic plasticity of the zoeal stages in this species.

\section{Materials and methods}

All samples are reference samples of parallel experiments. For further explanations of the experimental setup see Table 1.

Sampling and maintenance of adults

Fishermen caught ovigerous Cancer setosus by scuba diving at different sites around Antofagasta, Northern Chile $\left(23^{\circ} 45^{\prime} \mathrm{S}, 70^{\circ} 27^{\prime} \mathrm{W}\right.$; November 2005 , January 2006,

Table 1 Cancer setosus: origin of samples with reference to related works

\begin{tabular}{llllll}
\hline Female ID & Experimental site & $\begin{array}{l}\text { Rearing } \\
\text { temperature }\left({ }^{\circ} \mathrm{C}\right)\end{array}$ & Date & Experiment & Reference samples for \\
\hline A + B & A & 16 & $02 / 2007$ & Larval development & Weiss et al. (2009a) \\
C + D & A & 16 & $11 / 2005$ & Embryonic development & Fischer et al. (2009a) \\
E + F & A & 20 & $01 / 2006$ & Embryonic development & Fischer et al. (2009a) \\
G + H & PM & 12 & $09+11 / 2006$ & Embryonic development & Fischer et al. (2009a) \\
I + J & PM & 16 & $09+11 / 2006$ & Embryonic development & Fischer et al. (2009a) \\
\hline
\end{tabular}

A Antofagasta, $P M$ Puerto Montt 
February 2007) and in Carelmapu, close to Puerto Montt in Central Southern Chile $\left(41^{\circ} 44^{\prime} \mathrm{S}, 73^{\circ} 41^{\prime} \mathrm{W}\right.$, September and November 2006). Crabs were immediately transferred to the laboratory and only crabs with eggs in the early blastula stage were considered for subsequent experiments. Sampling sites were chosen for representing the upper and lower temperature conditions encountered by C. setosus, which roughly range from 10 to $20^{\circ} \mathrm{C}$ mean annual sea surface temperature (SST) throughout its geographical range (Fischer 2009). Puerto Montt is located close to the southern limit of this species. In Antofagasta Bay, SST is significantly higher than in the surrounding Humboldt Current upwelling system $\left(+2-3^{\circ} \mathrm{C}\right)$ due to the bay's particular oceanographic conditions (Piñones et al. 2007), and thus SST is comparable to the temperature encountered by C. setosus at its northern distributional limit off Ecuador (Fischer et al. 2009b).

Two females (IDs A, B) (influence of temperature encountered during larval development) in Antofagasta were maintained individually in flow-through seawater aquaria (12 1) at ambient temperature $\sim 16.0^{\circ} \mathrm{C}$, while four females (IDs C, D, E, and F) (influence of temperature encountered during embryonic development on larval morphology) were held in 3,2001 flow-through aquaria ( $\leq 12$ ind./basin) under natural seasonal temperature conditions (up to 10 months; $16-23^{\circ} \mathrm{C}$ ) in Antofagasta. Larval samples of females $\mathrm{C}$ and $\mathrm{D}$ were taken immediately after hatching at $16^{\circ} \mathrm{C}$ in November 2005 and larval samples $\mathrm{E}$ and $\mathrm{F}$ were taken immediately after hatching at $20^{\circ} \mathrm{C}$ in January 2006. In Puerto Montt, four females (IDs G, H, I, and $\mathrm{J}$ ) were held in 5001 aquaria ( $\leq 9$ ind./basin). Here, temperatures were kept constant at 12 (IDs $\mathrm{G}, \mathrm{H}$ ) and $16^{\circ} \mathrm{C}$ (IDs I, J) in order to simulate the temperature conditions at oviposition and embryonic development from Northern and Southern Chile. The whole embryonic development of the eggs from the early blastula stage on took place at the respective experimental temperature. All females were kept in seawater at a salinity of 34 , in a 12:12-h light/dark cycle and were fed ad libitum with living Perumytilus purpuratus. The aquaria were cleaned and water temperature was recorded daily.

\section{Rearing of larvae}

Freshly hatched larvae were collected in filters receiving water from the overflow of the aquaria. Since most larvae hatched at night, samples were taken every morning. Filters were cleaned every evening to ensure daily larval age did not vary by more than $12 \mathrm{~h}$ (after Lovrich et al. 2003). For the experiment on the influence of temperature encountered during embryonic development on larval morphology, samples of freshly hatched, actively moving larvae were taken in Antofagasta (females A-F) and Puerto Montt (females G-J)
(Table 1). For the experiment of the influence of temperature on larval development, solely actively moving larvae of females A and B (Antofagasta) were transferred to bowls with $16^{\circ} \mathrm{C}$ filtered seawater and afterwards allowed to acclimate to the experimental temperatures $\left(16,20,24^{\circ} \mathrm{C}\right)$. Samples were taken at the first day of each available instar. We were only able to get Zoea II and Zoea III larvae from each experimental temperature, because unfavourable temperatures lead to high mortality rates of $C$. setosus larvae (Weiss et al. 2009a, b). Zoea IV and V larvae were only available at the optimum temperature of $20^{\circ} \mathrm{C}$ (Weiss et al. 2009a). Larvae were transferred into Eppendorf caps with $4 \%$ formalin buffered seawater. Samples were transferred to the Alfred Wegener Institute, Bremerhaven, for further analyses.

\section{Larval morphometry}

Digital pictures (Colour view soft imaging system) of each larva were taken using a stereo-microscope (Leica MZ12 5 ). Images were processed with the programme Cell* imaging software for life sciences microscopy (Olympus Soft Imaging Solutions GmbH). All measurements (Fig. 1) were taken along the dorsal surface of the morphological feature. Zoeal total length (TL) was measured from the telson furca along the dorsal curvature to the tip of the rostral carapace spine. The antenna was measured from its tip to the point of attachment at the carapace. The rostral carapace spine was measured from its tip to its basal indentation of the spine between the eyes. The dorsal and lateral spines were measured from the point of attachment of the carapace to the distal tip. The carapace length (CL) was measured from the

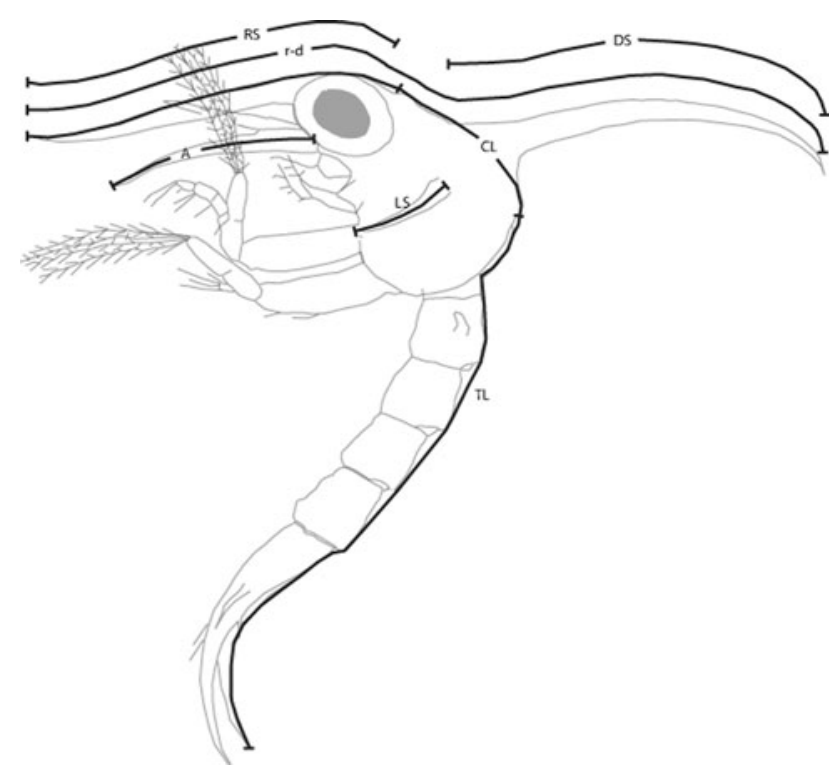

Fig. 1 Cancer setosus: Zoea I larvae. Thick black lines indicate measured parameters. $T L$ total body length, $r-d$ rostral-dorsal distance, $R S$ rostral spine, $D S$ dorsal spine, $L S$ lateral spine, $A$ antenna 
base of the rostrum to the posterior margin of the carapace. Additionally, the distance between the tip of the rostral and the tip of the dorsal spine was measured ( $r-d$ distance). The number of measured individuals per feature is given in Tables 2 and 3 .

\section{Statistical analyses}

All data were tested with the Mahalanobis distances test (Mahalanobis 1936) to exclude outliers from analysis. Ratios were transformed with an arcsin transformation prior analysis. The effects of temperature and location on instar characteristics were analysed with analysis of variance (ANOVA). Normal distribution of the dataset was tested with a Saphiro-Wilk $W$ test. Post-hoc tests were conducted with the student's $t$-test.

\section{Results}

Geographic differences

Freshly hatched Zoea I larvae of females reared at $16^{\circ} \mathrm{C}$ in Puerto Montt (southern Chile) were significantly larger in all measured parameters than Zoea I larvae of females reared at $16^{\circ} \mathrm{C}$ in Antofagasta (northern Chile; Fig. 2). In Puerto Montt, TL of freshly hatched Zoea I larvae was $13 \%$ longer $(p=0.0031, f=9.55)$; the rostral spine was $5 \%$ longer ( $p=0.0093, f=7.24$ ), the dorsal spine was $7 \%$ longer $(p<0.0001, f=18.98)$, the lateral spine was $4 \%$ longer $(p=0.0088, f=7.37)$, the $r-d$ was $17 \%$ longer $(p<0.0001$, $f=52.86)$, the carapace was $10 \%$ longer $(p<0.0001, f=$ 26.68) and the antenna was $4 \%$ longer $(p=0.0007$, $f=12.76$ ) than in Antofagasta (Fig. 2). The ratio of the measured parameters versus the carapace length (CL) revealed significant differences between the two locations. The TL:CL $(p=0.0001, f=17.09)$, the $r-d: C L(p<0.0001$, $f=2129.98)$, the RS:CL $(p=0.0003, f=14.66)$, the DS:CL $(p<0.0345, f=4.70)$ and the Antenna:CL $(p<0.0001$, $f=1335.30$ ) were significantly longer in larvae from the Antofagasta region (Table 4).

Temperature effect during embryonic development

Freshly hatched Zoea I larvae which experienced embryogenesis at 16 and $20^{\circ} \mathrm{C}$ in Antofagasta (Fig. 3a) revealed that larvae with embryonic development at colder temperatures have significantly (16\%) longer total length

Table 2 Cancer setosus: female identifications, and morphometric measures of Zoea I larvae hatched at different incubation temperatures in

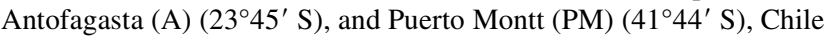

\begin{tabular}{llllllllll}
\hline Location & $\begin{array}{l}T \\
\left({ }^{\circ} \mathrm{C}\right)\end{array}$ & $\begin{array}{l}\text { Female } \\
\mathrm{ID}\end{array}$ & TL $(\mathrm{mm})$ & $r-d(\mathrm{~mm})$ & $\begin{array}{l}\text { Rostral } \\
\text { spine }(\mathrm{mm})\end{array}$ & $\begin{array}{l}\text { Dorsal } \\
\text { spine }(\mathrm{mm})\end{array}$ & $\begin{array}{l}\text { Lateral } \\
\text { spine }(\mathrm{mm})\end{array}$ & $\begin{array}{l}\mathrm{CL} \\
(\mathrm{mm})\end{array}$ & $\begin{array}{l}\text { Antenna } \\
(\mathrm{mm})\end{array}$ \\
& & & Mean $\pm \mathrm{SD}$ & Mean $\pm \mathrm{SD}$ & Mean $\pm \mathrm{SD}$ & Mean $\pm \mathrm{SD}$ & Mean $\pm \mathrm{SD}$ & $\mathrm{Mean} \pm \mathrm{SD}$ & $\mathrm{Mean} \pm \mathrm{SD}$ \\
\hline $\mathrm{A}$ & 16 & $\mathrm{~A} / \mathrm{B} / \mathrm{C} / \mathrm{D}$ & $2.56 \pm 0.26$ & $1.71 \pm 0.05$ & $0.80 \pm 0.07$ & $0.83 \pm 0.05$ & $0.32 \pm 0.03$ & $0.49 \pm 0.01$ & $0.45 \pm 0.03$ \\
& 20 & $\mathrm{E} / \mathrm{F}$ & $2.70 \pm 0.14$ & $1.78 \pm 0.10$ & $0.84 \pm 0.06$ & $0.85 \pm 0.09$ & $0.34 \pm 0.05$ & $0.50 \pm 0.01$ & $0.45 \pm 0.05$ \\
$\mathrm{PM}$ & 12 & $\mathrm{G} / \mathrm{H}$ & $2.85 \pm 0.20$ & $1.96 \pm 0.07$ & $0.87 \pm 0.06$ & $0.94 \pm 0.06$ & $0.39 \pm 0.05$ & $0.57 \pm 0.01$ & $0.50 \pm 0.06$ \\
& 16 & $\mathrm{I} / \mathrm{J}$ & $2.85 \pm 0.23$ & $1.96 \pm 0.09$ & $0.89 \pm 0.07$ & $0.94 \pm 0.06$ & $0.37 \pm 0.05$ & $0.59 \pm 0.01$ & $0.49 \pm 0.04$ \\
\hline
\end{tabular}

Measures given are: total length (TL), the distance between the tip of the rostral and the tip of the dorsal spine $(r-d)$, lengths of the rostral, dorsal, lateral spine, carapace length (CL) and antenna length. For details on measurements see "Materials and methods" section; $n=10$ in each treatment

Table 3 Cancer setosus: morphometric measures of Zoea II (ZII), Zoea III (ZIII), Zoea IV (ZIV) and Zoea V (ZV) larvae reared at different incubation temperatures in Antofagasta (A) $\left(23^{\circ} 45^{\prime} \mathrm{S}\right)$, Chile

\begin{tabular}{llcclllllll}
\hline Instar & $\begin{array}{l}T \\
\left({ }^{\circ} \mathrm{C}\right)\end{array}$ & $n$ & $\begin{array}{l}\text { Incubation } \\
\text { time (days) }\end{array}$ & TL $(\mathrm{mm})$ & $r-d(\mathrm{~mm})$ & $\begin{array}{l}\text { Rostral } \\
\text { spine }(\mathrm{mm})\end{array}$ & $\begin{array}{l}\text { Dorsal } \\
\text { spine }(\mathrm{mm})\end{array}$ & $\begin{array}{l}\text { Lateral } \\
\text { spine }(\mathrm{mm})\end{array}$ & $\begin{array}{l}\mathrm{CL} \\
(\mathrm{mm})\end{array}$ & $\begin{array}{l}\text { Antenna } \\
(\mathrm{mm})\end{array}$ \\
& & & & Mean $\pm \mathrm{SD}$ & Mean $\pm \mathrm{SD}$ & Mean $\pm \mathrm{SD}$ & Mean $\pm \mathrm{SD}$ & Mean $\pm \mathrm{SD}$ & Mean $\pm \mathrm{SD}$ & $\mathrm{Mean} \pm \mathrm{SD}$ \\
\hline ZII & 16 & 16 & $10-23$ & $3.43 \pm 0.26$ & $2.27 \pm 0.17$ & $1.01 \pm 0.08$ & $1.03 \pm 0.16$ & $0.38 \pm 0.07$ & $0.70 \pm 0.02$ & $0.50 \pm 0.06$ \\
& 20 & 18 & $7-17$ & $3.43 \pm 0.36$ & $2.10 \pm 0.26$ & $0.99 \pm 0.01$ & $0.92 \pm 0.20$ & $0.42 \pm 0.09$ & $0.68 \pm 0.02$ & $0.52 \pm 0.03$ \\
& 24 & 21 & $6-18$ & $3.15 \pm 0.32$ & $1.74 \pm 0.29$ & $0.88 \pm 0.01$ & $0.63 \pm 0.30$ & $0.36 \pm 0.07$ & $0.61 \pm 0.02$ & $0.52 \pm 0.04$ \\
ZIII & 16 & 8 & $23-34$ & $4.39 \pm 0.30$ & $2.84 \pm 0.27$ & $1.34 \pm 0.10$ & $1.29 \pm 0.33$ & $0.42 \pm 0.07$ & $0.88 \pm 0.04$ & $0.70 \pm 0.06$ \\
& 20 & 3 & $16-28$ & $3.80 \pm 0.31$ & $2.29 \pm 0.34$ & $1.04 \pm 0.10$ & $1.08 \pm 0.28$ & $0.48 \pm 0.07$ & $0.80 \pm 0.06$ & $0.62 \pm 0.08$ \\
ZIV & 20 & 14 & $25-33$ & $5.85 \pm 0.49$ & $3.94 \pm 0.34$ & $1.71 \pm 0.10$ & $1.83 \pm 0.24$ & $0.44 \pm 0.10$ & $1.26 \pm 0.14$ & $0.82 \pm 0.11$ \\
ZV & 20 & 6 & $27-39$ & $7.69 \pm 0.34$ & $4.83 \pm 0.31$ & $2.01 \pm 0.10$ & $2.21 \pm 0.21$ & $0.42 \pm 0.13$ & $1.47 \pm 0.16$ & $0.99 \pm 0.13$ \\
\hline
\end{tabular}

Measures given are: total length (TL), the distance between the tip of the rostral and the tip of the dorsal spine $(r-d)$, lengths of the rostral, dorsal, lateral spine, carapace length (CL) and antenna length. For details on measurements see "Materials and methods" section 


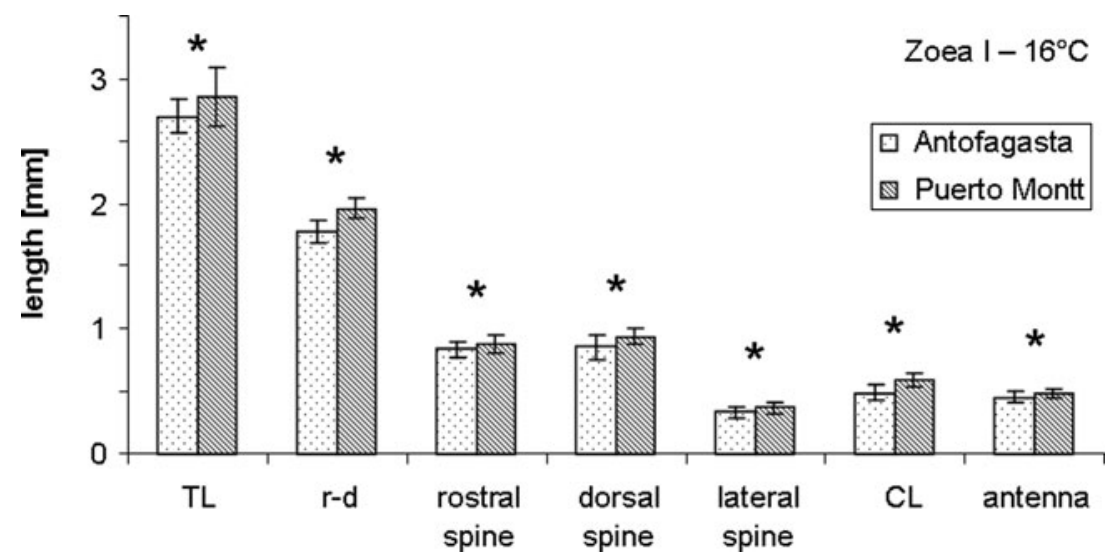

Fig. 2 Cancer setosus: morphometric measurements of Zoea I larvae hatched from eggs incubated at $16^{\circ} \mathrm{C}$ in Antofagasta $\left(23^{\circ} 45^{\prime} \mathrm{S}\right)$ and Puerto Montt ( $41^{\circ} 44^{\prime}$ S), Chile. Measures given are: total length (TL), the distance between the tip of the rostral and the tip of the dorsal spine $(r-d)$, lengths of the rostral, dorsal, and lateral spine. For details on measurements see "Materials and methods" section. All measured parameters were significantly different $(p<0.01)$, *significant difference
Table 4 Cancer setosus: ratios of spine lengths and antenna versus carapace length

$A$ Antofagasta, $P M$ Puerto Montt, ZI, ZII, ZIII: zoeal stages, total Length (TL), the distance between the tip of the rostral and the tip of the dorsal spine $(r-d)$, lengths of the rostral (RS), dorsal (DS), lateral spine (LS), antenna and carapace length (CL). Significantly shorter spines are given in bold

\begin{tabular}{lllllllll}
\hline Location & Instar & $\begin{array}{l}\text { Temperature } \\
\left({ }^{\circ} \mathrm{C}\right)\end{array}$ & TL:CL & $r-d: C L$ & RS:CL & DS:CL & LS:CL & Antenna:CL \\
\hline A & ZI & 16 & 5.51 & 3.63 & 1.71 & 1.74 & 0.68 & 0.92 \\
PM & ZI & 16 & $\mathbf{4 . 8 6}$ & $\mathbf{3 . 3 4}$ & $\mathbf{1 . 5 1}$ & $\mathbf{1 . 6 0}$ & 0.63 & $\mathbf{0 . 8 4}$ \\
$\mathrm{A}$ & ZI & 16 & 5.51 & 3.63 & 1.71 & 1.74 & 0.68 & 0.92 \\
$\mathrm{~A}$ & ZI & 20 & $\mathbf{5 . 1 5}$ & 3.44 & 1.61 & 1.66 & 0.65 & 0.91 \\
PM & ZI & 12 & 4.99 & 3.44 & 1.53 & 1.65 & 0.68 & 0.87 \\
PM & ZI & 16 & 4.86 & 3.34 & 1.51 & 1.60 & 0.63 & 0.84 \\
$\mathrm{~A}$ & ZII & 16 & 5.00 & 3.23 & 1.44 & 1.47 & 0.53 & 0.71 \\
$\mathrm{~A}$ & ZII & 20 & 5.06 & 3.10 & 1.45 & 1.36 & 0.63 & 0.77 \\
$\mathrm{~A}$ & ZII & 24 & 5.14 & 2.84 & 1.44 & $\mathbf{1 . 0 3}$ & 0.58 & 0.85 \\
$\mathrm{~A}$ & ZIII & 16 & 4.99 & 3.24 & 1.52 & 1.47 & 0.48 & 0.80 \\
$\mathrm{~A}$ & ZIII & 20 & 4.75 & 2.86 & $\mathbf{1 . 3 0}$ & 1.35 & 0.60 & 0.77 \\
\hline
\end{tabular}

$(p=0.0082, f=7.50)$, a $7 \%$ longer rostral spine $(p=$ $0.0279, f=5.09)$, a $8 \%$ longer $r-d$ distance $(p=0.0049$, $f=8.59)$ and a $3 \%$ longer dorsal spine $(p=0.0226$, $f=5.49$ ). The ratio of appendages and CL showed that freshly hatched Zoea I reared at $20^{\circ} \mathrm{C}$ had slightly shorter spines than larvae reared at $16^{\circ} \mathrm{C}$; this effect was significant $(p=0.0203, f=5.71)$ in the TL:CL ratio (Table 4).

Freshly hatched Zoea I larvae from Puerto Montt in contrast, which experienced embryogenesis at 12 and $16^{\circ} \mathrm{C}$ did not show any significant differences in the measured parameters (total length, $r-d$ distance, rostral spine, dorsal spine, lateral spine, and antenna) (Fig. 3b) or in the calculated appendages versus carapace length ratios.

Temperature effect during larval development

In Antofagasta, Zoea II larvae reared at 16,20 , and $24^{\circ} \mathrm{C}$ showed significant differences in larval TL $(p=0.0468$, $f=3.40)$, the length of the rostral $(p=0.0009, f=8.76)$ and dorsal spine $(p=0.0014, f=8.13)$, the $r-d$ distance $(p=0.0001, f=12.07)$ and the CL $(p=0.0072, f=5.64)$ (Fig. 4a). In those differing parameters larvae reared at $24^{\circ} \mathrm{C}$ were significantly smaller than larvae at 16 and $20^{\circ} \mathrm{C}$, except for the larval $\mathrm{TL}$ at $16^{\circ} \mathrm{C}$, which showed an intermediate TL to that found at 16 and $24^{\circ} \mathrm{C}$ (Fig. 4a). The appendage versus carapace length ratios showed that the DS:CL was significantly smaller $(p=0.023, f=4.24)$ in Zoea II larvae reared at $24^{\circ} \mathrm{C}$ (Table 4). Additionally, those larvae showed deformations of the carapace and the dorsal spine; the dorsal spine is not broken, but reduced and the carapace shows lateral bulging (Fig. 5). Zoea III larvae were only available at 16 and $20^{\circ} \mathrm{C}$, because all larvae maintained at $24^{\circ} \mathrm{C}$ died during ecdysis, as this is known to be the most critical point during the larval cycle (Anger 2001; Weiss et al. 2009a). Zoea III larvae reared at $20^{\circ} \mathrm{C}$ were significantly smaller than those reared at $16^{\circ} \mathrm{C}$, as evident in total length $(p=0.0159, f=8.39), r-d$ distance 
Fig. 3 Cancer setosus: morphometric measurements of Zoea I larvae hatched from eggs incubated at a 16 and $20^{\circ} \mathrm{C}$ in Antofagasta $\left(23^{\circ} 45^{\prime} \mathrm{S}\right)$, and $\mathbf{b} 12$ and $16^{\circ} \mathrm{C}$ in Puerto Montt $\left(41^{\circ} 44^{\prime}\right.$

$\mathrm{S})$, Chile. Measures given are: total length (TL), the distance between the tip of the rostral and the tip of the dorsal spine $(r-d)$, lengths of the rostral, dorsal, and lateral spine, the carapace length (CL) and the antenna length. For details on measurements see "Materials and methods" section $(p<0.05$, *significant difference)
Fig. 4 Cancer setosus: morphometric measurements of zoeal stages for a Zoea II larvae incubated at 16,20 , and $24^{\circ} \mathrm{C}$ and $\mathbf{b}$ Zoea III larvae incubated at 16 and $20^{\circ} \mathrm{C}$ in Antofagasta $\left(23^{\circ} 45^{\prime} \mathrm{S}\right)$, Chile. Measures given are: total length (TL), the distance between the tip of the rostral and the tip of the dorsal spine $(r-d)$, lengths of the rostral, dorsal, and lateral spine, the carapace length (CL) and the antenna length. For details on measurements see "Materials and methods" section. Significant differences are marked with different letters (ZII: $p<0.01$, ZIII: $p<0.05)$

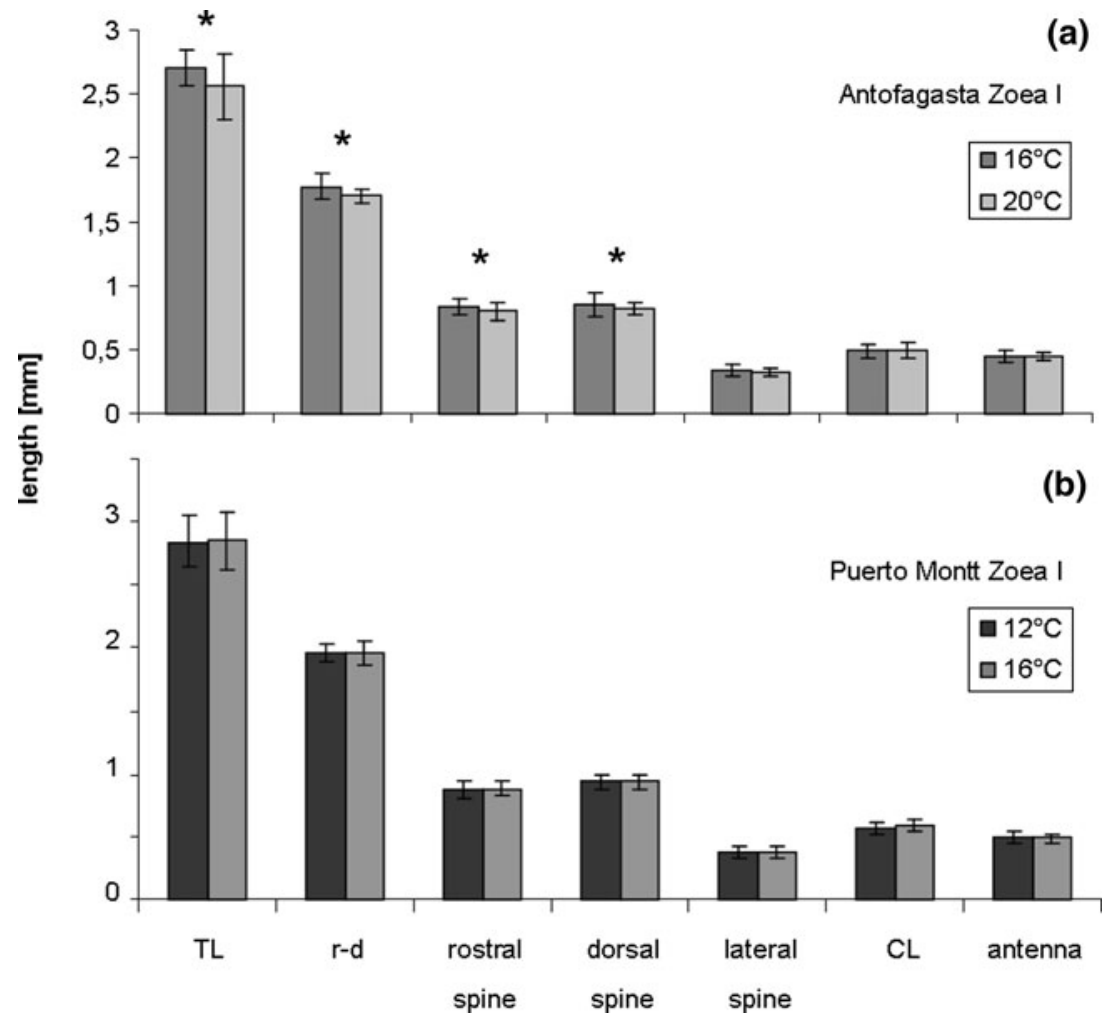

(a)

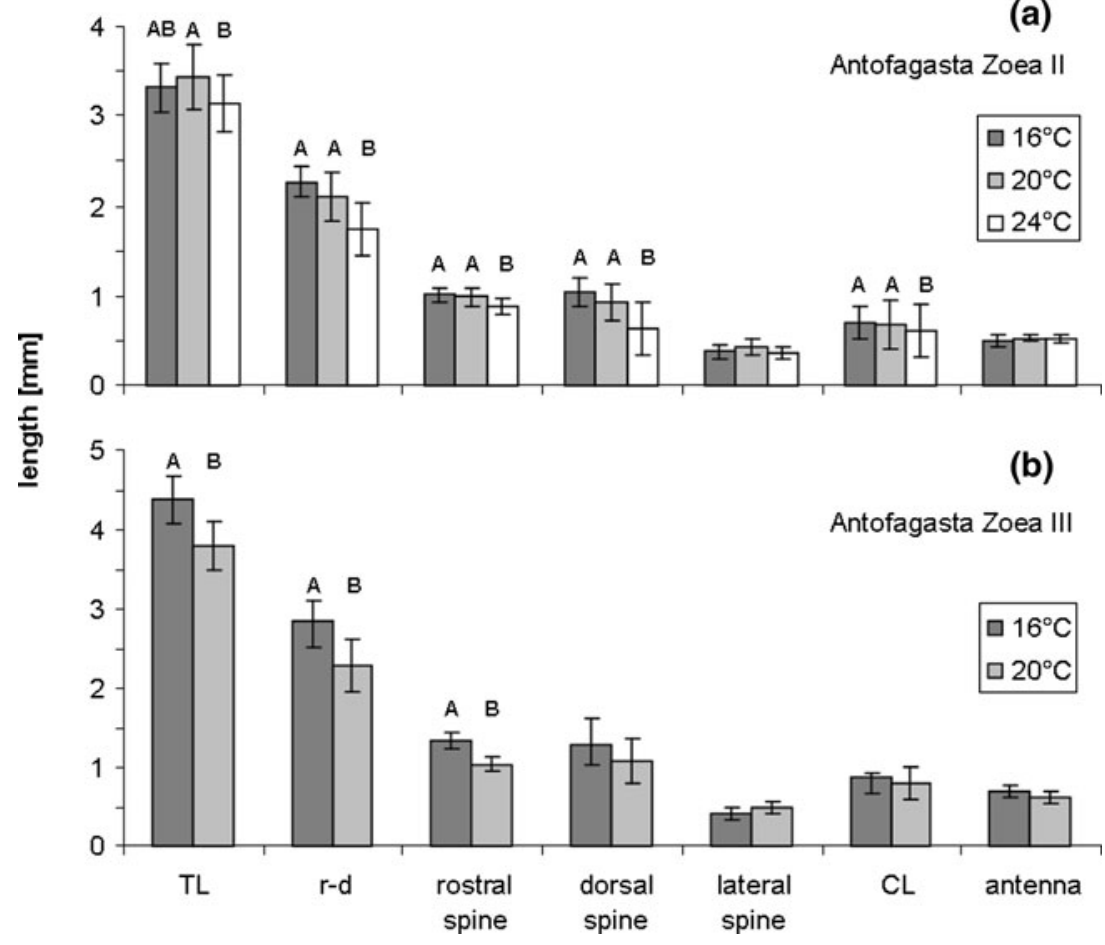

$(p=0.0162, f=8.33)$ and rostral spine $(p=0.0011$, $f=20.46$; Fig. $4 \mathrm{~b}$ ). The appendage versus carapace length ratios showed that larvae reared at $20^{\circ} \mathrm{C}$ have shorter appendages, but this was only significant in the RS:CL $(p=0.0196, f=6.64)$.

\section{Discussion}

In the present study, the intraspecific variability of morphological characteristics of Cancer setosus early zoeal stages in relation to rearing temperature and geographical origin is 


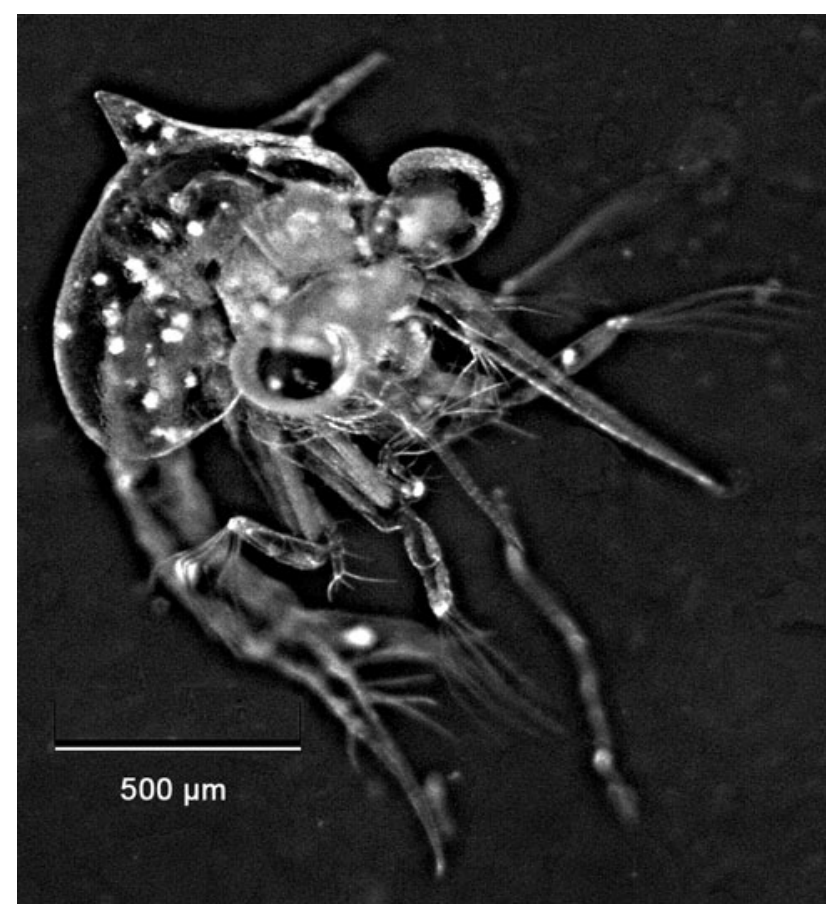

Fig. 5 Cancer setosus: Zoea III larvae reared at $24^{\circ} \mathrm{C}$, showing a reduced dorsal spine and lateral bulging of the carapace

presented. Early zoeal stages from the southern region, where temperatures are colder (SST $10-16^{\circ} \mathrm{C}$ ) (mean values of the years 1982-2006, SHOA 2009) were significantly larger than larvae from the northern population (SST $16-20^{\circ} \mathrm{C}$ ). Latitudinal variation (accompanied by variation in temperature) is generally known to lead to higher growth efficiencies at lower temperatures (e.g. Clarke 1983; Clarke 2003; Heilmayer et al. 2004). Animals from colder regions have to invest less energy in the maintenance of the standard metabolism and therefore can direct more energy into growth. Fischer et al. (2009a) suggested that blastula eggs of C. setosus at Puerto Montt at $12^{\circ} \mathrm{C}$ were provided by $30 \%$ more fatty acids as blastula eggs produced in Antofagasta at $20^{\circ} \mathrm{C}$, and larvae utilise a higher percentage of fatty acids at colder temperatures. Indeed, these findings may indicate that a metabolism based on fatty acids might produce larger larvae. Surprisingly, the appendages of freshly hatched Zoea I larvae from the Antofagasta region were relatively longer than those in Puerto Montt. This might be explained by a thermal acclimation of larvae. In the Antofagasta region $16^{\circ} \mathrm{C}$ can already be regarded as a cold temperature, where the formation of longer spines can serve as a protection against predators during the elongated pelagic life phase. Another explanation would be that instead of an increase in size, warm temperatures might result in the rapid formation of morphological structures due to a certain imbalance between development and growth (Wehrtmann and López 2003 and publications cited therein).
A comparison of the morphology of freshly hatched Zoea I larvae of females from Puerto Montt reared at $12^{\circ}$ and $16^{\circ} \mathrm{C}$ did not show any differences in total length, $r-d$ distance, rostral spine, dorsal spine, lateral spine, carapace length, antenna or in the calculated ratios of appendages versus carapace length. The energy provisioning with higher lipid content of larvae from the south seems to act as a protection shield not only for unfavourable conditions like food shortage but also makes larvae more tolerant to temperature changes.

Freshly hatched Zoea I larvae from the northern region in contrast show a morphological variability when embryonic development took place at comparable temperature ranges. Again, larvae reared at colder temperatures were larger indicating that development that is mainly based on protein depletion may be more sensitive to temperature changes. Differences in the morphological characteristics are especially pronounced in TL, the rostral spine, and the $r-d$ distance. All these parameters include the rostral spine. Shirley et al. (1987) showed that a subtraction of the rostral spine from parameters measured prohibit significant differences. This is not the case in the present study, but nonetheless the characteristic of the rostral spine seems to be sensitive to temperature.

A differentiation of two different species of Pachygrapsus was not possible by means of morphological traits in larvae, but through adult morphology and genetic analyses (Schubart et al. 2005). Larvae in this study from different oceans and coasts (East Pacific, West Atlantic east Atlantic) but from similar temperature regimes showed highest similarity in morphometric traits. These examples may suggest that within limits temperature has a more pronounced effect on larval morphology than genetic deviation. This is supported by the circumstance that $C$. setosus exhibits very little genetic diversity along its entire distribution range (Gomez-Uchida et al. 2003).

The comparison between Zoea II larvae reared at different temperatures showed that warmer temperatures lead to significantly smaller larvae, independent of the instar, at $24^{\circ} \mathrm{C}$, a temperature typically found during strong El Niño events (SHOA 2009). These observations coincide with the approximate upper thermal tolerance threshold suggested for larvae of the species (Weiss et al. 2009b).

Regarding the $r-d$ distance measured by Quintana and Saelzer (1986) from larvae of the region of Concepción it is apparent that although Concepción is $13^{\circ}$ south of Antofagasta and water temperatures are lower $\left(11-14^{\circ} \mathrm{C}\right)$, larvae measured in that study seem to be generally smaller. This might be due to the measurement technique used in their study. In the present study the $r-d$ distance was measured along the curvatures, whereas Quintana and Saelzer (1986) measured the straight distance between both spine tips (see Quintana 1981). 
A comparison with cancrid decapods from the North Sea, Cancer pagurus, shows that larvae of this congener hatch with much larger sizes ( $2.5 \mathrm{~mm} r-d$ distance) (Ingle 1981; Hartnoll and Mohamedeen 1987) than larvae of C. setosus over its distributional range, but the final zoeal instar (Zoea V) of larvae reared at $20^{\circ} \mathrm{C}$ in the present study has nearly the same size in both species $(\sim 4.83 \mathrm{~mm})$. This is also reflected in the cumulative growth rates measured in carbon gain (from ZI to ZV) (Weiss et al. 2009a, b). Those are exceptionally high for $C$. setosus $(2,940 \%)$ and comparably low for $C$. pagurus (876\%).

Morphological variability in decapod larvae has been frequently discussed as an ecological strategy and adaptation to changing environmental conditions (Anger 2001). Those energy saving traits of producing larger eggs and early larval instars at higher latitudes (colder temperatures) once more support the controversially discussed but often supported "Thorson's rule" (Mileikovsky 1971; Clarke 1993; Thatje and Bacardit 2000) that appears to be particularly useful for the evaluation of energetic trait-offs in decapods (Thatje et al. 2003). Fischer et al. (2009b) found more energy rich fatty acids in the southern than in the northern population eggs, independent of the incubation temperature. This might indicate a genetic adaptation to colder temperatures and might be a selection in the direction of non-feeding larvae and hence towards lecithotrophic development, which is indicating the beginning of an abbreviated development (Thatje et al. 2005). It is widely accepted, that a development with many larval stages represents a phylogenetically ancestral state, while an abbreviation of the larval stage is said to be derived (Strathmann 1978; Anger 2001). Especially in an unfavourable habitat for planktotrophic, extended larval phase (short period of food availability, temperatures close to the lower limit, and high predation pressure) an abbreviated larval development would enhance survival rates. Quintana and Saelzer (1986) showed that zoeal development of $C$. setosus larvae of a population from Coliumo Bay (Concepción, central Chile) takes about 60 days under natural temperature conditions $\left(13.5-14.6^{\circ} \mathrm{C}\right)$, while larvae from the Antofagasta region have a 1.5 times exceeded zoeal development at $16^{\circ} \mathrm{C}$ and show higher survival rates (Weiss et al. 2009b), and larvae from Concepcion are capable to develop through all zoeal instars at lower temperatures. These findings indicate a better cold adaptation of larvae originating from a southern population (see also Fischer and Thatje 2008; Fischer et al. 2009a) and from an evolutionary point of view could be considered ancestral to further abbreviated larval developments (Strathmann 1978), which is favourable for larvae from colder regions.

Although acclimation to colder temperatures leads to a relatively short larval development, the pelagic phase might still be longer in the southern population, where larvae are subject of predation for a longer period of time. However, a synergetic effect of a larger total length and elongated spines in colder regions might be that larvae stand better chances for survival by being protected from certain predators.

The herein reported phenotypic plasticity in early zoeal larvae enables this species to locally respond to some extent to the inter-decadal warming induced by El Niño, but it should be underlined that strong EN events exceed the upper temperature threshold in this species and are lethal for larval instars.

Acknowledgments We would like to thank Marcelo Oliva (Universidad Antofagasta, Chile) for providing workspace in his laboratory and Aldo Pacheco for help with larval culture maintenance. Special thanks are due to Sönke Fischer for providing the samples from Puerto Montt and for contributing to this manuscript. This study is conducted in the frame of the EU-FP6-INCO project CENSOR (Climate variability and El Niño Southern Oscillation: Implications for natural coastal resources and management) (Contract no. 511071), and received additional funding from the Marine Biodiversity and Ecosystem Functioning Network of Excellence MarBEF (Contract no. GOCE-CT-2003-505446). Monika Weiss was supported by a travel grant of the DAAD (contract no. $415 \mathrm{D} / 07 / 47120)$. The study is CENSOR publication No. 0386.

\section{References}

Anger K (2001) The biology of decapod crustacean larvae. A.A. Balkema Publishers, Lisse, Crustacean Issues 14, $420 \mathrm{pp}$

Brillon S, Lambert Y, Dodson J (2005) Egg survival, embryonic development, and larval characteristics of northern shrimp (Pandalus borealis) females subject to different temperature and feeding conditions. Mar Biol 147(4):895-911

Clarke A (1983) Life in cold water: the physiological ecology of polar marine ectotherms. Oceanogr Mar Biol Ann Rev 21:341-453

Clarke A (1993) Egg size and egg composition in polar shrimps (Caridea; Decapoda). J Exp Mar Biol Ecol 168(2):189-203

Clarke A (2003) Costs and consequences of evolutionary temperature adaptation. Trends Ecol Evol 18(11):573-581

Criales MM, Anger K (1986) Experimental studies on the larval development of the shrimps Crangon crangon and C. allmanni. Helgol Mar Res 40(3):241-265

Cuesta JA, Luppi TA, Rodriguez A, Spivak ED (2002) Morphology of the megalopal stage of Chasmagnathus granulatus Dana, 1851 (Crustacea: Decapoda: Brachyura: Varunidae), with comments on morphological anomalies. Proc Biol Soc Wash 115(2):391-402

Fischer S (2009) Temperature effects on reproduction and early lifehistory traits in the brachyuran crab Cancer setosus in the Humboldt Current System. PhD thesis, University of Bremen, Germany, pp 1-118

Fischer S, Thatje S (2008) Temperature-induced oviposition in the brachyuran crab Cancer setosus along a latitudinal cline: aquaria experiments and analysis of field-data. J Exp Mar Biol Ecol 357(2):157-164

Fischer S, Thatje S, Graeve M, Paschke K, Kattner G (2009a) Bioenergetics of early life-history stages of the brachyuran crab Cancer setosus in response to changes in temperature. J Exp Mar Biol Ecol 374:160-166

Fischer S, Thatje S, Brey T (2009b) Early egg traits in Cancer setosus (Decapoda, Brachyura) from Northern and Central-Southern Chile: effects of temperature and maternal size. Mar Ecol Prog Ser 377:193-202 
Garth JS, Stephenson W (1966) Brachyura of the Pacific coast of America, Brachyrhyncha: Portunidae. Allan Hancock monographs in marine biology, vol 1. Allan Hancock Foundation; University of Southern California, Los Angeles, pp 1-151

Giménez L (2002) Effects of prehatching salinity and initial larval biomass on survival and duration of development in the zoea 1 of the estuarine crab, Chasmagnathus granulata, under nutritional stress. J Exp Mar Biol Ecol 270(1):93-110

Gomez-Uchida D, Weetman D, Hauser L, Galleguillos R, Retamal M (2003) Allozyme and AFLP analysis of genetic population structure in the hairy edible crab Cancer setosus from the Chilean coast. J Crust Biol 23(2):486-494

Hartnoll RG, Mohamedeen H (1987) Laboratory growth of the larvae of six British crabs. J Exp Mar Biol Ecol 107(2):155-170

Heilmayer O, Brey T, Poertner HO (2004) Growth efficiency and temperature in scallops: a comparative analysis of species adapted to different temperatures. Funct Ecol 18(5):641-647

Ingle RW (1981) The larval and post-larval development of the Edible crab, Cancer pagurus Linnaeus (Decapoda: Brachyura). Bull Br Mus Nat Hist (Zool) 40(5):211-236

Kunisch M, Anger K (1984) Variation in development and growth rates of larval and juvenile spider crabs Hyas araneus reared in the laboratory. Mar Ecol Prog Ser 15(3):293-301

Lovrich GA, Thatje S, Calcagno JA, Anger K, Kaffenberger A (2003) Changes in biomass and chemical composition during lecithotrophic larval development of the southern king crab, Lithodes santolla (Molina). J Exp Mar Biol Ecol 288(1):65-79

Mahalanobis PC (1936) On the generalised distance in statistics. Proc Natl Inst Sci India 12:49-55

Mileikovsky SA (1971) Types of larval development in marine bottom invertebrates, their distribution and ecological significance: a re-evaluation. Mar Biol 10(3):193-213

Pestana D, Ostrensky A (1995) Occurrence of an alternative pathway in the larval development of the crab Chasmagnathus granulata Dana, 1851 under laboratory conditions. Hydrobiologia 306(1):33-40

Piñones A, Castilla JC, Guiñez R, Largier JL (2007) Nearshore surface temperatures in Antofagasta bay (Chile) and adjacent upwelling centers. Cienc Mar 33(1):37-48

Quintana R (1981) Desarollo larval de tres especies de cancridae bajo condiciones de laboratorio (Decapoda, Brachyura). Ph.D. thesis. Universidad de Concepcion, Concepcion, $115 \mathrm{pp}$

Quintana R, Saelzer H (1986) The complete larval development of the Edible Crab, Cancer setosus Molina and observations on the prezoeal and first zoeal stages of $C$. coronatus Molina (Decapoda: Brachyura, Cancridae). J Fac Sci Hokkaido Univ Ser VI Zool 24(4):267-303

Schubart CD, Cuesta JA, Felder DL (2005) Phylogeography of Pachygrapsus transversus (Gibbes, 1850): the effect of the American continent and the Atlantic Ocean as gene flow barriers and recognition of Pachygrapsus socius Stimpson, 1871 as a valid species. Nauplius 13:99-113
SERNAPESCA (2006) Servício nacional de pesca. http://www. sernapesca.cl

Shirley SM, Shirley TC, Rice SD (1987) Latitudinal variation in the Dungeness crab, Cancer magister: zoeal morphology explained by incubation temperature. Mar Biol 95:371-376

SHOA (2009) Servicio Hidrográfico y Oceanográfico, Armada de Chile. http://www.shoa.cl

Silva PV, Luppi TA, Spivak ED, Anger K (2009) Reproductive traits of an estuarine crab, Neohelice (=Chasmagnathus) granulata (Brachyura: Grapsoidea: Varunidae), in two contrasting habitats. Sci Mar (Barc) 73(1):117-127

Strathmann RR (1978) The evolution and loss of feeding larval stages of marine invertebrates. Evolution 32(4):894-906

Thatje S, Bacardit R (2000) Morphological variability in larval stages of Nauticaris magellanica (A. Milne-Edwards, 1891) (Decapoda: Caridea: Hippolytidae) from South American waters. Bull Mar Sci 66(2):375-398

Thatje S, Schnack-Schiel S, Arntz WE (2003) Developmental tradeoffs in Subantarctic meroplankton communities and the enigma of low decapod diversity in high southern latitudes. Mar Ecol Prog Ser 260:195-207

Thatje S, Hillenbrand CD, Larter R (2005) On the origin of Antarctic marine benthic community structure. Trends Ecol Evol 20(10):534-540

Thatje S, Heilmayer O, Laudien J (2008) Climate variability and El Niño Southern Oscillation: implications for natural coastal resources and management. Helgol Mar Res 62(1):5-14

Wehrtmann IS (1991) How important are starvation periods in early larval development for survival of Crangon septemspinosa larvae? Mar Ecol Prog Ser 73(2-3):183-190

Wehrtmann IS, Albornoz L (1998) Larval development of Nauticaris magellanica (Milne Edwards, 1891) (Decapoda: Caridea: Hippolytidae), reared under laboratory conditions. Bull Mar Sci 62(1):45-72

Wehrtmann IS, Albornoz L (2003) Larvae of Nauticaris magellanica (Decapoda: Caridea: Hipploytidae) reared in the laboratory differ morphologically from those in nature. J Mar Biol Assoc UK 83(5):949-957

Wehrtmann IS, Kattner G (1998) Changes in volume, biomass, and fatty acids of developing eggs in Nauticaris magellanica (Decapoda: Caridea): a latitudinal comparison. J Crust Biol 18(3):413-422

Wehrtmann IS, López GA (2003) Effects of temperature on the embryonic development and hatchling size of Betaeus emarginatus (Decapoda: Caridea: Alpheidae). J Nat Hist 37(18):2165-2178

Weiss M, Heilmeyer O, Brey T, Thatje S (2009a) Influence of temperature on the zoeal development and elemental composition of the cancrid crab, Cancer setosus Molina, 1782 from Pacific South America. J Exp Mar Bio Ecol 376:48-54

Weiss M, Thatje S, Heilmayer H, Anger K, Brey T, Keller M (2009b) Influence of temperature on the larval development of the edible crab, Cancer pagurus. J Mar Biol Assoc UK 89(4):753-759

Wolff M, Soto M (1992) Population dynamics of Cancer polyodon in La Herradura Bay, northern Chile. Mar Ecol Prog Ser 85:69-81 